\title{
The Nexus of Climate Change, Land Use, and Conflicts
}

\author{
Rebecca Froese $^{1,2,3} \cdot$ Janpeter Schilling ${ }^{1,2,3}$
}

Published online: 2 February 2019

(C) The Author(s) 2019

\begin{abstract}
Purpose of Review The aim of this paper is to explore the nexus of climate change, land use, and conflict. A particular focus is placed on the human security risks associated with the three elements.

Recent Findings Climate change has been perceived as a "threat multiplier," directly aggravating human security risks, such as food and water insecurity, as well as indirectly contributing to (violent) conflict in regions vulnerable to climate change. In addition to climate change-related environmental risks, such as droughts and floods, land and land use can be affected by climate mitigation and adaptation measures. These include, for instance, large-scale renewable energy plants and relocation efforts.

Summary It is not only important for decision-makers to take climate change impacts into account but also to assess the indirect risks associated with climate change mitigation and adaptation measures. For further research, it is hence promising to explore how conflict-sensitive approaches to climate change adaptation and mitigation can be developed.
\end{abstract}

Keywords Climate change $\cdot$ Conflict $\cdot$ Land use $\cdot$ Renewable energy $\cdot$ REDD+

\section{Introduction}

Climate change and resource scarcity are increasingly perceived as multipliers of risks and threats that exacerbate existing societal problems such as poverty, injustice, social insecurity, violence, terrorism, or civil war $[1,2,3 \cdot \bullet, 4 \bullet \bullet, 5]$. As one of the most abundant, but also most contested resources, land and land use are subject to a variety of conflicts worldwide. In 2014, these security and conflict implications made it to the international policy agenda when the Intergovernmental Panel on Climate Change (IPCC), for the first time, included a chapter on human security in its fifth assessment report, and thus raising attention to the fact that climate change is

This article is part of the Topical Collection on Climate Change and Conflict

Janpeter Schilling schilling@uni-landau.de

1 Peace Academy Rhineland-Palatinate, University of Koblenz-Landau, Landau, Germany

2 Institute for Environmental Sciences, Research Group Landuse Conflicts, University of Koblenz Landau, Landau, Germany

3 Institute of Geography, Research Group Climate Change and Security (CLISEC), University of Hamburg, Hamburg, Germany undermining livelihoods of millions of people across the globe $\left[6^{\bullet}\right]$.

However, the pathways from climate change, resource access, and distribution to conflict are indirect, highly complex, and linked to other factors such as political, economic, and social conflicts, including ineffective institutions, social inequalities, or low economic development [4••]. These pathways may have local or global origins in the form of changing temperature and rainfall patterns, causing extreme events such as floods and droughts, and more gradual change such as sealevel rise. However, land scarcity is not only induced through natural climate-driven phenomena, but also through anthropogenic interference which can be broadly distinguished in two categories: (1) primary interference, such as forest degradation for agricultural expansion, urbanization on formerly agricultural land, or the competition for the use of urban space; and (2) secondary interference, such as large-scale renewable energy plants as mitigation of climate change or resettlement efforts as adaptation to climate change [7]. These measures aim at buffering the adverse effect of climate change in the region and making the local communities less vulnerable and more resilient to climate change [8]. Many of the mitigation and adaptation measures, however, require land and thus indirectly increase the pressure on land as a resource.

The aim of this paper is to explore the current research of climate change and conflict in the context of the altered 
resource of land, taking into account both the direct effects of climate change on land and land use as well as the indirect effects that may be introduced through climate mitigation and adaptation measures. We first describe our understanding of the interlinkages between the direct and indirect risks through a conceptual framework before we go into more detail on the impacts of climate change, adaptation, and mitigation on land use and conflicts. Finally, we conclude with implications of the current research for conflict-sensitive approaches to climate change adaptation and mitigation measures.

\section{Conceptual Framework}

Key concepts that describe the pathways in research on climate change and conflict are vulnerability and resilience. While vulnerability encompasses a variety of concepts such as sensitivity and adaptive capacity, we apply the official IPCC definition of vulnerability - " "the propensity or predisposition to be adversely affected" [9]. Concomitantly, we define resilience as the "ability of a group or community to withstand, recover, and learn from external disturbances" [10•]. Another important concept that research on climate and conflict often draws on is environmental security [11]. We define environmental security as "the absence of risk or threat to the environment a person or community depends on and lives in" [12]. While the securitization of climate change has been problematized [13], the benefits of a combination of the two concepts of resilience and environmental security have also been discussed recently [10 • . In terms of anthropogenic responses to climate change, we draw on the commonly used distinction between adaptation, "the process of adjustment to actual or expected climate and its effects," and mitigation, "human intervention to reduce the sources or enhance the sinks of greenhouse gases (GHGs)" [9]. In this paper, we cover both violent and non-violent conflicts. We understand conflict as a situation in which at least two actors (individuals, groups, states, etc.) perceive their goals, interests, beliefs, or actions as incompatible with each other. We speak of violent conflict when at least one of the conflict actors uses force to pursue its interest or to directly harm another conflict actor [14]. In this paper, we distinguish between two types of conflict. First, those that are directly related to the impacts of climate change (e.g. drought) and which mostly occur between or within communities, or between communities and the government. And second, conflicts that arise because of climate-related mitigation and adaptation measures, for instance, between project implementers, governments, and communities affected by the projects. "Project" refers to the climate adaptation or mitigation measure such as a wind park or certification of a forest under Reducing Emissions from Deforestation and Forest Degradation (REDD+). While all conflicts discussed in this paper are connected to global/ international and national levels, the focus of the conflict analysis is placed on the local level, where climate impacts are felt and projects are implemented (for the issue of scale see also Fig. 1 and [15]).

Figure 1 shows the connections between climate change, including mitigation and adaptation measures and their impacts on land, human security, and response options. Human security is understood as the "condition where people and communities have the capacity to manage stresses to their needs, rights, and values" [16]. We do not claim this figure to be complete. Nor do we want to suggest that the pathways from climate change to conflict or cooperation are apolitical. Indeed, history and institutions matter as political ecologists have rightly pointed out (see for instance [17]). Global climate targets (currently $2{ }^{\circ} \mathrm{C}$ ) and mitigation and adaptation measures are discussed and defined by states under the lead of the United Nations Framework Convention on Climate Change secretariat [18]. The land tenure system is usually set up by the national governments and implemented and enforced by government representatives at the local level. Land tenure includes land rights and rules to regulate the access to land, use of land, and protection of land against pollution and degradation, or as the FAO [7, 19] summarizes it: "tenure systems determine who can use what resources for how long and under what conditions."

The human security of people is both determined by how well a government provides for its people in terms of education, health, energy, and transport infrastructure, but it also depends on how well local communities sustain their livelihoods with limited support from the (central) government. Subsistence farming and nomadic pastoralism are just two examples. Particularly in the limited presence of government representation, informal institutions such as a council of elders or traditional chiefs matter in providing human security and determining whether a change in human security leads to cooperation or conflict [20].

The purpose of Fig. 1 is not to deny the importance of institutions, but rather to illustrate the complexity of links within the nexus of climate change, land, and conflict. Pronounced changes in the climate system, such as alterations in temperature and precipitation, whether natural or anthropogenic, apply stress to land through a variety of complex interactions (e.g., through changes in availability of water, soil, or biodiversity) (for example [6•], [4••]). Subsequent drought, erosion, or other interactions may result in land degradation or forced changes in land use (for example, [21, 22]). Such changes influence the livelihoods of the population in various ways and may lead to conflict or cooperation processes. In this paper, we focus on illustrating potential conflict implications, as covering the links between climate change, land use, and cooperation would go beyond the scope of this paper. These links are particularly addressed by the growing literature on environmental peacebuilding (see for instance [10•, 23]). 


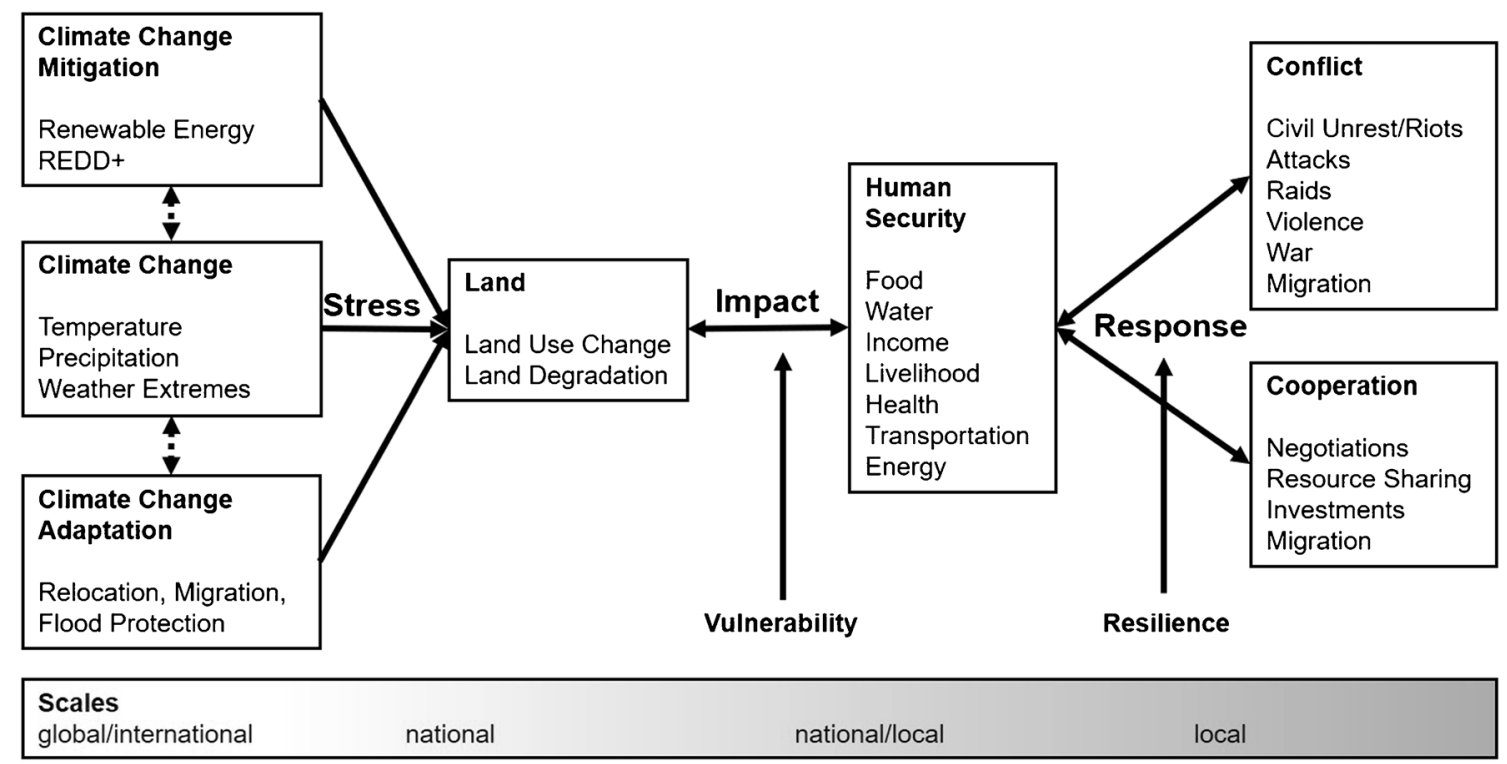

Fig. 1 Conceptual framework of direct and indirect effects of climate change on resource availability and potential conflict and cooperation dynamics (modified from Scheffran et al. [14])

Recent research highlights that climate change affects the availability of land not only directly, but also indirectly through increased usage of land for mitigation and adaptation measures $[3 \cdot \bullet]$. Large-scale mitigation efforts, such as renewable energy power plants and REDD+ measures, play an increasing role for land use, particularly in developing countries $[24,25 \cdot \bullet]$. When former communal land is acquired by the government or international investors to install large wind parks or concentrated solar power plants, the primary users of the land, may they be farmers, pastoralists, or indigenous people, are denied access to resources that sustain livelihoods and cultural identities [26•,27]. In a similar way, adaptation measures can affect land use and force land use change, for example, through relocation efforts or flood protection infrastructure. Relocation efforts include both voluntary and forced relocation as a consequence of mitigation or adaptation measures. For example, when people have to leave a forest in order to preserve it as a carbon sink under REDD+ or when people move away from coastal areas in anticipation of sealevel rise, floods, or storms (see next section). Planned and organized relocation efforts are a key element of many disaster risk reduction (DRR) strategies (see, for example, [28, 29]).

Stress on land and the resulting land use change and land degradation can have adverse impacts on human security. Depending on the vulnerability of the community, land degradation, biodiversity loss, or land scarcity can undermine livelihoods and hence human security, e.g., when subsistence farmers lose land or pastoralists lose access to pasture and water points. These described impacts on human security and their interdependencies can, in turn, provoke human responses that affect the social system and aggravate existing social instabilities [5]. These conflicts occur on subnational, national, or regional scales and may be non-violent or evolve into violent forms, such as riots, attacks, civil war, or forced migration, leading themselves to more social disruption and mistrust [20].

\section{Impacts of Climate Change on Land Use and Conflicts}

Increasing temperatures, higher precipitation variability, weather extremes, or sea-level rise due to climate change are considered to affect human security through a variety of interconnections in the coming decades $[4 \cdot \bullet, 6 \bullet]$. One of the interconnections is land use and land use change which are expected to be strongly influenced not only through the changing climatic conditions but also through human interference due to population growth, rapid urbanization, and consequent increasing pressure on ecosystem resources [30]. Whether humans react cooperatively or with conflict to these dwindling resources is not easy to foresee and depends on different parameters, such as their vulnerability or resilience. In addition, links between climate and conflict are often indirect while human adaptive capacity to climate change is sensitive to conflict [31].

Potential links between climate change and (violent) conflict have been discussed as early as 2003 by Barnett [32], more concisely by Scheffran et al. [4*0] and most recently by Theisen [3••]. While neo-Malthusian-simplified links between violent conflict and environmental deprivation, as drawn by Homer-Dixon [11] or Bächler [33], have been widely criticized, the community of researchers is divided on whether links between climate and conflict might be drawn or rejected 
[5]. In Kenya, for example, several scholars have paid attention to violent livestock thefts (called "raids") between different nomadic pastoral groups and their relation to changes in precipitation. While Witsenburg and Adano [34] find a tripling of raids during the rainy season, which they explain with healthier stolen animals and less required attention for their own herds, Ember et al. [35] find higher intensities of livestock raids during drier months and drought years as pastoralists have to migrate further to find pasture and water and thus move closer to the territory of hostile groups, increasing the likelihood of violence. Schilling et al. [36] and Raleigh and Kniveton [37] argue that communal or rebel conflict events in several East African countries are influenced by a combination of resource scarcity and resource abundance, which are particularly sensitive to extreme rainfall variations. For Africa overall, the findings are ambivalent on whether climate change increases the risk of civil wars [38] or whether the climate "is not to blame" for such conflicts [39]. While the former study argues that increasing temperatures aggravate the conflict risk for agricultural households and entire societies through negative effects on agricultural and economic productivity, the latter argues that the roots for conflict in Africa are not be found in climate variability, but rather in the structural and contextual conditions, such as prevalent ethno-political exclusion, poor national economies, and the collapse of the Cold-War system. The latter findings are supported by Detges [1], who warns against misinterpretation of ambiguous quantitative study links between climate and conflict. And while direct impacts of climate change on conflict remain unclear, it is recognized that pressure on land and water and subsequent food scarcity could escalate lowintensity conflicts [40-42]. Such conflicts over resources related to land, such as the degradation of forests or arable land (through, e.g., wind and water erosion), mining, or dam projects are predominantly local or regional and less likely to become international threats. The study by Detges [1] finds that drought has little effect on short-term risks of violent conflict. However, he also highlights that the likelihood of sustained violence increases when drought is combined with unfavorable social and political conditions, such as political marginalization and poor citizen-government relations. These conditions favor the development of more radical attitudes or even violent interventions against the government.

\section{Impacts of Climate Change Adaptation on Land Use and Conflicts}

Adaptation to climate change is one of the responses to the increasing challenges that global environmental change imposes on human society. And while adaptation requires resources, not only in monetary terms but also in terms of knowledge, planning, and coordination, future vulnerability remains, among others, dependent on infrastructure investments, industrial strategic decisions, and rural and urban planning [43]. Few attempts have been made from the sociopolitical perspective to understand the potentially problematic effects of climate change adaptation $[3 \bullet \bullet, 44 \cdot]$. This section gives some examples of adaptation measures that influence land use and describes their conflict implications in rural and urban areas.

\section{Adaptation in Rural Areas}

Among the few studies on adaptation impacts on land use is the paper by Fezzi et al. [45] on Great Britain. The authors model how adaptation to climate change in agriculture is expected to affect aquatic ecosystems which could thus affect the availability of fresh water, wildlife, biodiversity, or carbon sequestration. A strong north-south divide is prevalent in the current agricultural system in Great Britain with more profitable areas in the drier southern lowlands than the wetter and colder highlands in the north. The results of the study point out that climate change will particularly benefit the northern and eastern midlands and uplands as higher temperatures will allow for higher livestock production and a larger share of arable land. However, the authors also highlight that the increased productivity of land comes along with a higher pressure on land, likely leading to emissions diffusing into rivers and thus increasing pressure on the environment as well as political pressure as it requires more effort to fulfill national and international water-quality standards. On the other hand, the models also present a potential diminution of pressure on the environment in the southern lowlands as higher temperatures and precipitation rates may reduce the viability of agricultural land, reduce the nutrient input from agriculture, and thus facilitate the adherence of water-quality standards [45].

As described in the section on direct impact of climate change on land use and conflict, climate or environmental changes affect human security and human development. The related effects on land use and land rights have become drivers of migration in the Pacific [46]. Sea-level rise and concomitant loss of land are becoming a severe risk for low-lying small island states and hence entire nation states, reviving the oftencalled worst-case scenario of migration or resettlement as an adaptation option [8]. Yet, although legal barriers for migration from many of the Pacific States to some other countries, mainly Australia and New Zealand, are small, it is rather expected that people would migrate internally to nearby islands that are located higher above sea level, due to cultural, spatial, and family proximity [7]. Nevertheless, increasing population density in the host communities may also implicate resource scarcity and a potential for conflicts between host communities and incoming migrants. 


\section{Adaptation in Urban Areas}

The previously described examples were mainly focusing on rural environments. Yet, urban areas also require an integrated approach to climate change and land use. While access to urban land is a generally pressing concern in the Global South, Lombard and Rakodi [47•] highlight that conflicts over urban land are often mentioned but seldomly investigated in depth, until now. Such conflicts are often associated with urban growth, inequality, and regulatory failures of states [47•] but increasingly also due to climate adaptation measures [48••]. Anguelovski et al. [48••] address the lack of research in the nexus of climate adaptation and land use planning in cities by assessing whether such measures prioritize vulnerable and marginalized people in the cities or whether they recreate existing inequalities. The authors found that maladaptation under the umbrella of resilience and climate adaptation can even bear double disadvantages for marginalized and, often, poor people through (1) infrastructure investments, land use regulations, or new protected areas affecting the livelihoods or even displacing people; and (2) protection of economically valuable land over low-income neighborhoods.

Green spaces have been recognized as important and valuable adaptation measures, for example, to mitigate the impact of urban heat islands and steadily growing traffic, and improvement of air quality through the uptake of pollutants and reductions of energy costs for the cooling of buildings. Such measures also increase the demand for urban space [49-51]. Additional pressure evolves through increasing property values in proximity to green spaces due to amenity and aesthetic reasons which may lead to gentrification of entire neighborhoods [52, 53]. Such developments, in the worst case, may even lead to forced relocation of disadvantaged people, who often informally inhabit land which becomes more valuable through urban growth and consequent land scarcity leading to community conflict [53]. In relation to green spaces, urban agriculture has been listed by the latest IPCC report as one climate change adaptation measure to increase food security and foster income generation and poverty alleviation [30], and thus foster the transformation into resilient cities (for example, Connelly and Bal [54]). However, urban agriculture is highly dependent on the availability of land in urban environments. Badami and Ramankutty [55] point out that urban agriculture is most feasible for the urban poor in high-income countries, where the availability of inexpensive and nutritious food tends to be high (see also [56]). The authors see urban agriculture benefits in terms of the productive use of land that otherwise might have been wasted, the greening of cities, and the social benefits of community building. On the other hand, Bryld [57] highlights the importance of the legalization of urban agriculture for securing land for the urban poor in developing countries in order to enhance livelihoods and mitigate the risks for conflicts, due to theft of crops from other urban agricultural fields, for example [57]. While the author also discusses potential problems of urban agriculture, such as health hazards due to pesticides and wastewater irrigation and the risk of taking up of spaces for houses, he also refers to the potential benefits of food security, economic advantages, such as income generation, and ecological advantages, such as increased humidity, improvement of air quality, and nutrient recycling, which is again available for soils in the urban environment. Such co-benefits of secure land tenure for the urban poor mitigate the risk for conflicts arising from insecure land tenure. The above-mentioned studies and arguments show that policies focusing on land, water use, or public space require a high degree of integration across policy fields. However, current decision-making is still lacking approaches that take into account the wider implications of adaptation and seek to incorporate synergies and trade-offs.

\section{Impacts of Climate Change Mitigation on Land Use and Conflicts}

Many international mitigation strategies that aim to address the global challenge of climate change have very local effects. For example, when efforts to offset carbon through nature conservation force communities to leave their land, conflicts between them and the government can be the result (see [58]). In this section, we focus exemplarily on two key mitigation strategies which feature strongly in the Paris Agreement and where land tenure is particularly important: (1) REDD+ to reduce emissions from conversion of forests and to increase carbon sinks through sustainable forest management, and (2) renewable energies, with a focus on large-scale wind power plants, to phase out fossil fuels.

\section{Conflict Implications of REDD+ Initiatives}

Reducing Emissions from Deforestation and Forest Degradation (REDD+) aims to create conditional, performance-based incentives for conservation and sustainable management of forests (REDD) and for enhancement of forest carbon stocks (the "+"). Since the climate negotiations in 2007 (COP 13) and the Bali Action Plan [59], REDD+ has been considered the leading option for climate change mitigation in the forest sector, which was planned to be initially publicly funded but was soon expedited through forest carbon offsets. Due to the failure of global carbon markets, the expected growth of REDD+ measures through private funding has failed to materialize $[60,61]$. However, through the Paris Agreement, the forest sector gained new attention as many developing countries have considered REDD+ as a substantial mitigation measure in their National Determined Contributions (NDCs) [62]. While the recognition of the importance of the forest and its mitigation potential in the global 
climate system is certainly positive, critiques and fears of emerging conflicts have already been formulated early in the process. Land tenure is one of the most important topics in the REDD+ discourse. However, increased tenure security for local communities resulting from REDD+ initiatives has only been observed to a small extent, while the loss of forest access, for example, has often been reported [25••, 63]. This section gives an overview of the negative externalities and the conflict implication of REDD+ initiatives focusing on land tenure and the use of the forest.

\section{Negative Externalities}

Right after the adoption of the Bali Action Plan in 2007 [59], the International Indigenous Peoples Forum on Climate Change (IIPFCC) very clearly stated their critique on the program, saying that "REDD+ [...] will increase the violation of our human rights, our rights to our lands, territories and resources, steal our land, cause forced evictions, prevent access and threaten indigenous agricultural practices, destroy biodiversity and cultural diversity and cause social conflicts. Under REDD/REDD+, states and carbon traders will take more control over our forests." This statement stressed the environmental, institutional, socio-cultural, and livelihood dimension that Bayrak and Marafa [64•] identified 10 years later as the key dimensions through which REDD+ initiatives impact forestdependent communities. All these dimensions are interrelated and bear a risk for conflicts between project implementers and local communities, for instance, when they are not allowed to use the forest to sustain their livelihoods and cultural identity. In the worst case, the commercialization of forest can displace entire communities $[65,66]$. Forest governance schemes, such as REDD+, often try to address these interconnected dimensions in order to increase the sustainability of the forest management [64•]. However, REDD+ initiatives are mostly based on a technical approach that focuses on the distribution of benefits rather than choosing a political lens that uses justice, legitimacy, and community rights as key principals [67•]. As forests in many countries are state-owned, forest-dependent communities and their traditional rights to use the forest are often neglected in governmental land use and forest management $[64 \cdot, 65,68]$.

\section{Conflict Implications of REDD+ in Low- and Middle-income Countries}

Various studies have shown that REDD+ initiatives require secure forest and carbon tenure to successfully advance forest conservation and strengthen livelihoods [69, 70]. However, REDD+ initiatives are often challenged by conflicting and unclear land tenure (see examples in [66]). Therefore, REDD+ initiatives often aim at improving tenure security. Sunderlin et al. [25••] investigated tenure efforts in five different countries (Brazil, Peru, Tanzania, Cameroon, and Indonesia) and their success in decreasing tenure insecurity. The authors found that REDD+ initiatives had limited impact on the improvement of tenure security, but where an impact was identified, it was positive. In contrast, Caron and Fenner [63] have found decreased or even loss of communal access to forests as a consequence of REDD+ projects in eastern Zambia. In most cases, the reduced accessibility for communities was driven by reallocation of land and conservationrelated restrictions. Caron and Fenner [63] identify three main decision-makers for forest governance: customary authorities, the state, and the private sector. While the customary authorities play a significant role in deciding on forest rules and controlling access, communities reported that their access to forests were mainly limited by restrictions and the presence of state authorities. At the same time, village leaders named land purchase and leases and subsequently imposed restrictions through the private sector as the main reason for lost forest access. The loss of communal access to forests has caused two conflict dynamics. First, between the communities whose livelihoods are based on the forest and the central government who aims to implement the REDD+ project. The conflict has escalated into violence in the form of arrests, beatings, and imprisonment of community members. As a consequence, women in particular avoid the forests, as they fear punishment, imprisonment, and being separated from their families [63]. The second conflict occurs between local chiefs and community members when the local chiefs are perceived by the communities as prioritizing interest of the private sector over those of the community. In the Zambian case, a chief reallocated a piece of customary land to lodge owners [63].

Myers et al. [67•] found that conflicts are more likely where unclear land tenure is prevalent. The authors identified contested boundaries and resources for agriculture and forests between two communities of which one claimed forest land for REDD+ which the other village previously used for agricultural purposes. In Vietnam, they also found communities who united against REDD+ initiatives from the state or against a company due to deforested rubber plantations [67•]. Many REDD+ initiatives have also experienced objection and protest, often because the local communities felt excluded from strategic planning and decision processes [67•]. Therefore, several studies have identified a need for participation of local communities, bottom-up approaches, and grassroot activities [71, 72]. However, participatory approaches need a careful design in order to fulfill the expectations that are imposed upon them, as it has been described by Benjaminsen [73]. The author investigates the "village-project" relationship during a participatory pre-REDD process in Zanzibar, in which the villagers aim to have "lost land" and "disappearing benefits" taken into consideration by taking part in the negotiation process. However, the influence on the project fell short of expectations of the villagers due to the ahistorical and apolitical approach of the project 
developers, forcing them into resistance and marginalizing them in the negotiation process rather than letting them participate in shaping the local dynamics of external environmental interventions, such as REDD+, which are following a global agenda.

The above-described examples illustrate the four main conflict constellations that we identify in the REDD+ literature: (1) state-community conflicts, (2) private sector-community conflicts, (3) inter-community conflicts, and (4) intracommunity conflicts.

\section{Conflict Implications of Large-scale Wind Power Plants}

Most scientists and decision-makers agree that a global transition from fossil fuel-based energy to renewable energy is necessary to mitigate climate change and keep the global mean temperature below the target of $2{ }^{\circ} \mathrm{C}$ (for example, $[74 \cdot, 75])$. Wind energy in particular plays an import role here. In 2017, renewable energies had an installed capacity of 1081 gigawatts (GW), of which wind energy accounted for more than 50\% [76]. Projections suggest that the currently installed wind energy capacity of $487 \mathrm{GW}$ will increase to $817 \mathrm{GW}$ by 2021 [24]. While this is certainly a positive development in terms of mitigating climate change, it is often neglected that wind parks require land and produce both benefits and negative externalities, which in turn can become a source of conflict. Using the example of wind parks and their implications on land use and conflicts, we show how developments at the global and international level, namely the target to limit global warming, affect the national level, such as expansion of renewable energy and dynamics at the local level. This section gives an overview of the conflict implications of wind parks with a particular focus on land and (see also Fig.1) land use. At the local level, the concept of "not in my backyard" (NIMBY) has been widely used to explain resistance against and conflicts around wind parks in developed countries. It essentially means that people are not generally opposing a wind park or any other facility, but that they do not want to have it in their surroundings $[77,78]$. More recently, the concept of NIMBY has been criticized for its limited explanatory power, for being "short-sighted" [79], 591] and for stereotyping local residents (e.g., [80-82]). For this review, we first describe the negative externalities, and then briefly discuss their conflict implications.

\section{Negative Externalities}

A key negative externality that objectors stress in developed countries is the negative aesthetic effect on the "place attachment" or "place identity" (e.g. [83]). Several researchers have argued that the more strongly people feel attached to their landscape, "viewscape" [84] or "seascape" (in the case of offshore wind parks, see [74•], 581]), the more likely they are to oppose wind parks because of aesthetic reasons [85]. Similarly, communities may fear a loss of cultural landscape and national heritage $[82,86,87]$. A conflict between local residents and wind park developers over the landscape and land use can be the result (see, for example, $[81,88])$. Hirsh and Sovacool [89], 706] have further argued for the USA that "the siting of turbines on rural mountaintops intensifies the already existing conflict between rural landowners and urban customers. Psychologically and symbolically, the turbines sometimes suggest an industrialization of rural residents' environment and the values they perceive as different from those of city folk" (see also [88]). In addition to identifying the rural-urban conflict constellation, Hirsh and Sovacool [89], 707] point out that wind parks create a general conflict potential as they make energy production visible and change the common image of energy as an "unseen and unthought-of commodity." Similarly, Ellis et al. [90•] have argued that some local residents oppose an offshore wind park proposal in Northern Ireland because of the anticipated negative visual impacts on the (tourism) economy and the aesthetic value of the landscape. The authors identify a conflict constellation between objectors and supporters of the wind park in which the objectors see the supporters as "being self-righteous" while the objectors are perceived by supporters as "self-interested, overly defensive and dogmatic" [90•], 537]. Here, the different scales, noted in Fig. 1, play a role. While the objectors mostly argue on a local level ("our place/surrounding") and partly on a national level ("national heritage"), the supporters of wind parks mostly stress the importance of the national (achieving national climate targets and "doing our part") and particularly the global ("fighting global warming") level. Another externality and source of conflict associated with wind parks in developed countries is the environmental impact, specifically avian mortality. Estimates for the USA suggest that between 140,000 and 328,000 birds are killed annually by wind turbines [81]. In Germany, about 250,000 bats are killed annually due to accidents with wind turbines [91]. Further, migratory routes of bats can be disrupted by wind power facilities [91]. These numbers motivate environmentally concerned people and environmental organizations to oppose and protest against the use of land for wind parks [92, 93]. Similar developments can be found for offshore wind parks (e.g., [90•]). Further direct negative externalities of wind parks for local residents may include health risks and a perceived reduction of quality of life because of noise emissions and shadow flicker caused by the rotor blades (e.g., [78, 90•, 94]). Physical danger can arise during the winter when icicles fall down from turbines [74•]. Concerns for a devaluation of land and decreasing property prices tend to rank higher in public opinion polls in developed countries $[95,96]$, see also $[97,98]$. 
Studies show that wind parks in developed countries do not only have negative externalities but also socioeconomic benefits in terms of land rents or sales, and employment and business opportunities [81, 90•,92]. However, the distribution of these benefits can become a source of conflict between neighboring communities or within one. For example, while parts of a community may benefit in terms of land rents or sales or because they are part of an energy cooperative, other parts may not benefit and hence only focus on the negative externalities of the wind park [87, 99].

\section{Conflict Implications of Wind Energy in Low- to Middle-income Countries}

All previously discussed studies have focused on developed countries where, so far, the majority of wind energy is produced [76]. However, in the future, it is expected that the installation of wind energy will grow faster in low- to middle-income countries $[25 \bullet \bullet, 75]$. The body of literature on conflict implications of wind parks in developing countries is growing but still limited. Since the socioeconomic and political context in most developing countries is so significantly different than in developed countries, the causes, mechanisms, intensities, and overall complexities of conflict over wind energy in developing countries are likely to be very different as well. One should hence be careful when applying lessons learned in developed countries to wind energy conflicts in low- and middle-income countries.

Among the few studies on wind energy in middle-income countries is the paper by Brannstrom et al. [26•] on Brazil. The authors find that the wind park, which is partly located on dunes and mangroves at the north-eastern coast of Brazil, does not only reduce environmental security by producing negative environmental externalities but also erodes livelihoods of traditional communities, threatens human security, and leads to territorial and resource-access conflicts. For example, during the construction phase, a large inter-dune freshwater lake was destroyed. Before, the lake had been used by the local communities as a source of fish and for leisure purposes. In addition, community members reported to be highly disappointed with the promises made by the wind park developers in terms of local employment and local economic effects [26•].

Disappointed community expectations for employment are also drivers of (partly) violent conflicts between local community members and the wind energy company in northern Kenya, where the largest wind park on the African continent has been completed in mid-2017 [100]. There, local community members, who were hoping for jobs with the wind park operator, protested against people from other communities being employed, and blocked the road to the wind park $[101 \bullet \cdot]$. These communities, who lived in proximity to the wind park, were already frustrated by the processes, as they were forced to move but not officially compensated, as they claimed [102]. Since the community did not hold any official land titles, the financial incentives in the form of land rents, as seen in wind park projects in developed countries, are not claimable by the communities. Here, one can see how land tenure systems at the national level differ between developed and developing countries and the systems have, hence, different implications for the local level, where people either benefit from land rights and compensations or not (see also Fig.1).

These two examples from Brazil and Kenya further show that because the level of income is generally lower in medium-developed and medium-developing countries, the expectations for financial and employment benefits tend to be higher than in developed countries. Disappointing these expectations can then become a source of potentially violent resistance, depending on the previous level of conflict in the area. In Brazil and Kenya, a top-down approach was chosen with little to no opportunity for local communities to participate in the siting of the wind park nor in further distributional processes. In Canada, this "decide-announcedefend" $[62,103]$ approach has shown to be highly conflictive and similar developments can be expected in developing countries. Differences between developing and developed countries exist in terms of land rights and (absence of) environmental regulation that generally tends to be in favor of wind park developers rather than communities in developing countries. Protecting the rights of local communities and managing their expectations for benefits will hence be important for mitigating conflict associated with wind parks in developing countries. Further, several authors have argued that the siting process is critical. "A collaborative style in siting" is found to be "more effective than top-down planning" [63, 103], see also [74•, 92]. This is supported by several studies that suggest that opposition to wind parks in developed countries is strongest at the planning stage and weaker once the wind park is complete and operational (e.g., [74•, 82]). However, Petrova [79], 589] suggests that "it is possible for initial opposition to turn into support, and vice versa." In general, the existence of trusted and neutral bodies providing unbiased information on the project, transparent communication, and the possibility for local communities to participate and influence the project tend to reduce local opposition and the risk of conflict [80, 81, $85,104]$. In developing countries, the social contract between the central government and communities in remote and marginalized rural communities (where wind parks tend to be constructed) is often already weak. If the communities feel that they are mostly exposed to the externalities of the wind park without benefitting in terms of employment and development, wind parks can further undermine the trust in the government that is perceived as unable or unwilling to protect the community's social and ecological values $[101 \bullet \bullet, 104]$. 


\section{Conclusions}

With this paper, we review the nexus of climate change, land use, and conflict in both direct effects of climate change on land use and conflicts as well as indirect implications through mitigation and adaptation efforts. We find an extensive body of literature on direct effects, for example, drought-related land use conflicts, with diverging opinions on whether global warming increases the risk for conflicts or not. We further identify research gaps in detailed investigations on the indirect land use and conflict implications of climate mitigation and adaptation measures. Initiatives supporting these measures draw on leading policy developments such as the Paris Agreement and concomitant available financing to take action but often lack the recognition of the negative externalities and conflict implications of adaptation and mitigation measures. Therefore, we join other authors in warning against adaptation and mitigation measures like the expansion of wind energy and REDD+ to become "green grabbing" [105] or "conservation fad" [106] that reproduce historically grown and existing inequalities (see also [67•]). Further research should hence focus on developing conflict-sensitive approaches to climate mitigation and adaptation measures ([63] make a similar call for more community inclusion), and thus include these conflicts into the climate governance debate. Conflict sensitivity implies analyzing the local context and avoiding the creation of greed and grievances that may become a source of conflict. The concept further implies to be sensitive to existing conflict dynamics and to evaluate how the proposed project affects these. This goes beyond the do-no-harm principle in safeguarding against, for example, violation of human rights and land rights, but it means to conduct a comprehensive analysis of the potential impacts of the proposed project (for conflict sensitivity and assessments, see for instance $[15,107-109])$. Failure to apply a conflict-sensitive approach increases the risk that climate change mitigation and adaptation measures aggravate or create local conflicts.

Acknowledgements We are thankful for the helpful comments from the external reviewers.

Funding information The overall work is supported by the University of Koblenz-Landau, the School of Integrated Climate System Sciences (SICSS) at the University of Hamburg and a grant of the National Geographic Society.

\section{Compliance with Ethical Standards}

Conflict of Interest On behalf of all authors, the corresponding author states that there is no conflict of interest.

Human and Animal Rights and Informed Consent This article does not contain any studies with human or animal subjects performed by any of the authors.

Open Access This article is distributed under the terms of the Creative Commons Attribution 4.0 International License (http:// creativecommons.org/licenses/by/4.0/), which permits unrestricted use, distribution, and reproduction in any medium, provided you give appropriate credit to the original author(s) and the source, provide a link to the Creative Commons license, and indicate if changes were made.

Publisher's Note Springer Nature remains neutral with regard to jurisdictional claims in published maps and institutional affiliations.

\section{References}

Papers of particular interest, published recently, have been highlighted as:

- Of importance

•• Of major importance

1. Detges A. Climate and conflict: reviewing the statistical evidence. Berlin: Adelphi; 2017.

2. WBGU, Wissenschaftlicher Beirat der Bundesregierung Globale Umweltveränderungen. World in transition: climate change as a security risk. London: Earthscan; 2008.

3.• Theisen OM. Climate change and violence: insights from political science. Curr Clim Chang Rep. 2017;3(4):210-21. https://doi.org/ 10.1007/s40641-017-0079-5. Provides a recent overview on the topic of climate change and conflict. After reviewing the relevant literature, the article calls for an increased focus on the political consequences of adaptation and mitigation.

4.• Scheffran J, Brzoska M, Kominek J, Link PM, Schilling J. Climate change and violent conflict. Science. 2012;336(6083): 869-71. https://doi.org/10.1126/science.1221339. Widely cited, this paper gives a concise introduction to the field. Includes a table with questions to explore the causes and effects of climate-conflict linkages.

5. Ide T, Link MP, Scheffran J, Schilling J. The climate-conflict Nexus: pathways, regional links, and case studies. In: Brauch GH, Oswald Spring Ú, Grin J, Scheffran J, editors. Handbook on sustainability transition and sustainable peace. Cham: Springer International Publishing; 2016.

6. Adger WN, Pulhin JM, Barnett J, Dabelko GD, Hovelsrud GK, Levy M, et al. Human security. In: Barros VR, Field CB, Dokken DJ, Mastrandrea MD, Mach KJ, Bilir TE, et al., editors. Climate Change 2014: Impacts, Adaptation, and Vulnerability. Part B: Regional Aspects. Contribution of Working Group II to the Fifth Assessment Report of the Intergovernmental Panel on Climate Change. Cambridge, United Kingdom and New York, USA: Cambridge University Press; 2014. Provides a human security perspective on the nexus of climate change and violent conflict.

7. Barnett J, Chamberlain N. Migration as climate change adaptation: implications for the Pacific. In: Burson B, editor. Climate Change and Migration, South Pacific Perspectives. Wellington, New Zealand: Institute of Policy Studies, Victoria University of Wellington; 2010. p. 51-60.

8. Boncour P, Burson B. Climate change and migration in the South Pacific region: policy perspectives. Policy Q. 2009;5(4):13-20.

9. IPCC. Annex II: Glossary. In: Mach KJ, Planton S, von Stechow C, editors. Climate Change 2014: Synthesis Report. Contribution of Working Groups I, II and III to the Fifth Assessment Report of the Intergovernmental Panel on Climate Change. Geneva, Switzerland: IPCC; 2014.

10. Schilling J, Nash SL, Ide T, Scheffran J, Froese R, von Prondzinski P. Resilience and environmental security: towards joint application in peacebuilding. Glob Chang Peace Secur. 2017;29(2):107-27. https://doi.org/10.1080/14781158.2017. 1305347. Provides an overview of strengths and weaknesses 
of resilience and environmental security. Develops a framework to combine the two concepts with the aim to apply them jointly in peacebuilding projects.

11. Homer-Dixon T. Environmental scarcities and violent conflict: evidence from cases. Int Secur. 1994;19(1):5-40.

12. Vivekananda J, Schilling J, Mitra S, Pandey N. On shrimp, salt and security: livelihood risks and responses in South Bangladesh and East India. Environ Dev Sustain. 2014;16(6):1141-61. https:// doi.org/10.1007/s10668-014-9517-x.

13. Selby J, Hoffmann C. Rethinking climate change, Conflict and Security. Geopolitics. 2014;19(4):747-56. https://doi.org/10. 1080/14650045.2014.964866.

14. Scheffran J, Link PM, Schilling J. Theories and models of climatesecurity interaction: framework and application to a climate hot spot in North Africa. In: Scheffran J, Brzoska M, Brauch HG, Link PM, Schilling J, editors. Climate change, human security and violent conflict: challenges for societal stability. Hexagon Series on Human and Environment Security and Peace. Berlin: Springer; 2012.

15. Schilling J, Saulich C, Engwicht N. Introduction: a local to global perspective on resource governance and conflict. Confl Secur Dev. 2018;18(6):433-61. https://doi.org/10.1080/14678802.2018. 1532641.

16. Barnett J, Adger WN. Climate change, human security and violent conflict. Polit Geogr. 2007;26(6):639-55. https://doi.org/10.1016/ j.polgeo.2007.03.003.

17. Peluso NL, Watts M, editors. Violent environments. Ithaca, London: Cornell University Press; 2001.

18. UNFCCC, United Framework Convention on Climate Change. About the Secretariat. https://unfccc.int/about-us/about-thesecretariat (2018). Accessed 19/10/2018.

19. FAO. Land tenure and rural development. Rome: FAO; 2002.

20. Scheffran J, Brzoska M, Brauch HG, Link PM, Schilling J, editors. Climate change, human security and violent conflict: challenges for societal stability. Berlin: Springer; 2012.

21. Ahmed KF, Wang G, You L, Yu M. Potential impact of climate and socioeconomic changes on future agricultural land use in West Africa. Earth Syst Dynam. 2016;7(1):151-65. https://doi.org/10. 5194/esd-7-151-2016.

22. Theisen OM, Gleditsch NP, Buhaug H. Is climate change a driver of armed conflict? Clim Chang. 2013;117(3):613-25. https://doi. org/10.1007/s10584-012-0649-4.

23. Ide T. Space, discourse and environmental peacebuilding. Third World Q. 2016;38:1-19. https://doi.org/10.1080/01436597.2016. 1199261.

24. GWEC, Global Wind Energy Council. Global wind report - 2016. Brussels: GWEC; 2017.

25.• Sunderlin WD, de Sassi C, Sills EO, Duchelle AE, Larson AM, Resosudarmo IAP, et al. Creating an appropriate tenure foundation for REDD+: the record to date and prospects for the future. World Dev. 2018;106:376-92. https://doi.org/10.1016/j.worlddev.2018. 01.010. Assesses the success of REDD+ in securing land tenure for village residents in five countries (Brazil, Peru, Cameroon, Tanzania and Indonesia).

26. Brannstrom C, Gorayeb A, JdS M, Loureiro C, AJdA M, da Silva $\mathrm{EV}$, et al. Is Brazilian wind power development sustainable? Insights from a review of conflicts in Ceara State. Renew Sustain Energy Rev. 2017;67:62-71. https://doi.org/10.1016/j. rser.2016.08.047. One of a few papers that addresses the conflict implications of wind parks in Brazil.

27. Barbier EB, Tesfaw AT. Can REDD+ save the forest? The role of payments and tenure. Forests. 2012;3(4):881-95. https://doi.org/ 10.3390/f3040881.

28. Dikmen N. Sustainable relocation in rural areas: an investigation in Cukur Village, Turkey. Eur J Sustain Dev. 2018;7(1):59-74. https://doi.org/10.14207/ejsd.2018.v7n1p59.
29. King D, Bird D, Haynes K, Boon H, Cottrell A, Millar J, et al. Voluntary relocation as an adaptation strategy to extreme weather events. Int J Disaster Risk Reduct. 2014;8:83-90. https://doi.org/ 10.1016/j.ijdrr.2014.02.006.

30. Revi A, Satterthwaite DE, Aragón-Durand F, Corfee-Morlot J, Kiunsi RBR, Pelling M, et al. Urban areas. In: Field CB, Barros VR, Dokken DJ, Mach KJ, Mastrandrea MD, Bilir TE, et al., editors. Climate change 2014: impacts, adaptation, and vulnerability. Part A: global and sectoral aspects. Contribution of Working Group II to the Fifth Assessment Report of the Intergovernmental Panel of Climate Change. Cambridge, United Kingdom and New York, NY, USA: Cambridge University Press; 2014.

31. Scheffran J. The security risks of climate change: vulnerabilities, threats, conflicts and strategies. In: Brauch HG, Oswald Spring Ú, Mesjasz CG, John K-MP, Chourou B, Dunay P, et al., editors. Coping with global environmental change, disasters and security. Hexagon Series on Human and Environmental Security and Peace. Berlin: Springer; 2011.

32. Barnett J. Security and climate change. Glob Environ Chang. 2003;13(1):7-17.

33. Bächler G. Environmental degradation in the south as a cause of armed conflict. In: Carius A, Lietzmann KM, editors. Environmental change and security: a European perspective. Berlin: Springer; 1999.

34. Witsenburg KM, Adano WR. Of rain and raids: violent livestock raiding in northern Kenya. Civil Wars. 2009;11(4):514-38. https:// doi.org/10.1080/13698240903403915.

35. Ember CR, Abate Adem T, Skoggard I, Jones EC. Livestock raiding and rainfall variability in northwestern Kenya. Civil Wars. 2012;14(2):159-81. https://doi.org/10.1080/13698249. 2012.679497.

36. Schilling J, Akuno M, Scheffran J, Weinzierl T. On raids and relations: climate change and pastoral conflict in northern Kenya. In: Bronkhorst S, Bob U, editors. Conflict-sensitive adaptation to climate change in Africa. Berlin: Berliner Wissenschaftsverlag; 2014.

37. Raleigh C, Kniveton D. Come rain or shine: an analysis of conflict and climate variability in East Africa. J Peace Res. 2012;49(1):5164. https://doi.org/10.1177/0022343311427754.

38. Burke MB, Miguel E, Satyanath S, Dykema JA, Lobell DB. Warming increases the risk of civil war in Africa. Proc Natl Acad Sci. 2009;106(49):20670-4.

39. Buhaug H. Climate not to blame for African civil wars. Proc Natl Acad Sci. 2010;107(38):16477-82.

40. Benjaminsen TA, Alinon K, Buhaug H, Buseth JT. Does climate change drive land-use conflicts in the Sahel? J Peace Res. 2012;49(1):97-111. https://doi.org/10.1177/0022343311427343.

41. Goulden M, Few R. Climate change, water and conflict in the Niger River basin. London: International Alert; 2011.

42. von Uexkull N. Sustained drought, vulnerability and civil conflict in Sub-Saharan Africa. Polit Geogr. 2014;43(0):16-26. https://doi. org/10.1016/j.polgeo.2014.10.003.

43. Fankhauser S. Adaptation to climate change. Ann Rev Resour Econ. 2017;9(1):209-30. https://doi.org/10.1146/annurevresource-100516-033554.

44. Javeline D. The most important topic political scientists are not studying: adapting to climate change. Perspect Polit. 2014;12(2): 420-34. https://doi.org/10.1017/S1537592714000784.

Highlights the importance and points out the lack of studying adaptation in the political sciences and suggests potential ways forward.

45. Fezzi C, Harwood AR, Lovett AA, Bateman IJ. The environmental impact of climate change adaptation on land use and water quality. Nat Clim Chang. 2015;5(3):255-60.

46. Bedford R, Bedford C. International migration and climate change: a post-Copenhagen perspective on options for Kiribati 
and Tuvalu. In: Burson B, editor. Climate change and migration: South Pacific perspectives. Wellington, New Zealand: Institute of Policy Studies, Victoria University of Wellington; 2010.

47. Lombard M, Rakodi C. Urban land conflict in the Global South: towards an analytical framework. Urban Stud. 2016;53(13):268399. https://doi.org/10.1177/0042098016659616. Develops a framework for land conflict analysis in cities and explores the drivers, dynamics and outcomes of urban land conflicts.

48.• Anguelovski I, Shi L, Chu E, Gallagher D, Goh K, Lamb Z, et al. Equity impacts of urban land use planning for climate adaptation: critical perspectives from the global north and south. J Plan Educ Res. 2016;36(3):333-48. https://doi.org/10.1177/ $0739456 X 16645166$. Provides a recent analysis of the connections between climate adaptation and land use planning in cities and highlighting the risk of double disadvantages for marginalized people through maladaptation.

49. Gill SE, Handley JF, Ennos AR, Pauleit S. Adapting cities for climate change: the role of the green infrastructure. Built Environ. 2007;33(1):115-33.

50. Mathey J, Rößler S, Lehmann I, Bräuer A, editors. Urban green spaces: potentials and constraints for urban adaptation to climate change. Dordrecht: Springer Netherlands; 2011.

51. Govindarajulu D. Urban green space planning for climate adaptation in Indian cities. Urban Climate. 2014;10:35-41. https://doi. org/10.1016/j.uclim.2014.09.006.

52. Haq SMA. Urban green spaces and an integrative approach to sustainable environment. J Environ Prot. 2011;2(5):8-608. https://doi.org/10.4236/jep.2011.25069.

53. Atkinson R. The evidence on the impact of gentrification: new lessons for the urban renaissance? Eur J Hous Pol. 2004;4(1): 107-31.

54. Connelly RI, Bal PG. Local networks of resilience and climate adaptation: the case of Istanbul. In: Filho WL, Musa H, Cavan G, O'Hare P, Seixas J, editors. Climate Change Adaptation, Resilience and Hazards. Berlin: Springer; 2016.

55. Badami MG, Ramankutty N. Urban agriculture and food security: a critique based on an assessment of urban land constraints. Glob Food Sec. 2015;4:8-15. https://doi.org/10.1016/j.gfs.2014.10. 003.

56. Beaulac J, Kristjansson E, Cummins S. A systematic review of food deserts, 1966-2007. Prev Chronic Dis. 2009;6(3):A105-A.

57. Bryld E. Potentials, problems, and policy implications for urban agriculture in developing countries. Agric Hum Values. 2003;20(1):79-86.

58. Cavanagh C, Benjaminsen TA. Virtual nature, violent accumulation: the 'spectacular failure' of carbon offsetting at a Ugandan National Park. Geoforum. 2014;56:55-65. https://doi.org/10. 1016/j.geoforum.2014.06.013.

59. UNFCCC. United framework convention on climate change. The Bali Action Plan. Bali: UNFCCC; 2007.

60. Brockhaus M, Di Gregorio M, Mardiah S. Governing the design of national REDD+: an analysis of the power of agency. Forest Policy Econ. 2014;49:23-33. https://doi.org/10.1016/j.forpol. 2013.07.003.

61. Enrici A, Hubacek K. Business as usual in Indonesia: governance factors effecting the acceleration of the deforestation rate after the introduction of REDD+. Energy Ecol Environ. 2016;1(4):183-96. https://doi.org/10.1007/s40974-016-0037-4.

62. Hein J, Guarin A, Frommé E, Pauw P. Deforestation and the Paris climate agreement: an assessment of REDD+ in the national climate action plans. Forest Policy Econ. 2018;90:7-11.

63. Caron C, Fenner S. Forest access and polycentric governance in Zambia's Eastern Province: insights for REDD+. Int For Rev. $2017 ; 19$ (3):265-77. https://doi.org/10.1505/ 146554817821865108 .
64. Bayrak M, Marafa L. Ten years of REDD+: a critical review of the impact of REDD+ on forest-dependent communities. Sustainability. 2016;8(7):620. Provides an in-depth analysis on the impact of REDD+ on forest-dependent communities and develops a framework for a holistic implementation of REDD+, incorporating forest-dependent communities.

65. Khatri DB, Marquardt K, Pain A, Ojha H. Shifting regimes of management and uses of forests: what might REDD+ implementation mean for community forestry? Evidence from Nepal. Forest Policy Econ. 2018;92:1-10. https://doi.org/10.1016/j.forpol.2018. 03.005 .

66. Leach M, Scoones I, editors. Carbon conflicts and forest landscapes in Africa. Oxon: Routledge; 2015.

67. Myers R, Larson AM, Ravikumar A, Kowler LF, Yang A, Trench T. Messiness of forest governance: how technical approaches suppress politics in REDD+ and conservation projects. Glob Environ Chang. 2018;50:314-24. https://doi.org/10.1016/j.gloenvcha. 2018.02.015. Provides a reasonable distinction between distributive justice and rights-based/social justice and highlights the importance of addressing political objections in conservation projects such as REDD+.

68. Nepstad DC, Boyd W, Stickler CM, Bezerra T, Azevedo AA. Responding to climate change and the global land crisis: REDD+, market transformation and low-emissions rural development. Philos Trans R Soc B Biol Sci. 2013;368(1619):20120167. https://doi.org/10.1098/rstb.2012.0167.

69. Asare RA, Kyei A, Mason JJ. The community resource management area mechanism: a strategy to manage African forest resources for REDD+. Philos Trans R Soc B Biol Sci. 2013;368(1625):20120311. https://doi.org/10.1098/rstb.2012. 0311.

70. Duchelle AE, Cromberg M, Gebara MF, Guerra R, Melo T, Larson A, et al. Linking forest tenure reform, environmental compliance, and incentives: lessons from REDD+ initiatives in the Brazilian Amazon. World Dev. 2014;55:53-67. https://doi.org/ 10.1016/j.worlddev.2013.01.014.

71. Rodriguez-Ward D, Larson AM, Gordillo Ruesta H. Top-down, bottom-up and sideways: the multilayered complexities of multilevel actors shaping forest governance and REDD+ arrangements in Madre de Dios, Peru. Environ Manag. 2018;62(1):98-116. https://doi.org/10.1007/s00267-017-0982-5.

72. Wallbott L, Florian-Rivero EM. Forests, rights and development in Costa Rica: a political ecology perspective on indigenous peoples' engagement in REDD+. Confl Secur Dev. 2018;6:493-520. https://doi.org/10.1080/14678802.2018.1532643.

73. Benjaminsen G. Between resistance and consent: project-village relationships when introducing REDD+ in Zanzibar. Forum Dev Stud. 2014;41(3):377-98. https://doi.org/10.1080/08039410. 2014.961953.

74. Karydis M. Public attitudes and environmental impacts of wind farms: a review. Glob NEST J. 2013;15(4):585-604. Provides useful insights into how resistance against wind parks changes from the planning to the implementation phase of the wind project.

75. Wiser R, Yang Z, Hand M, Hohmeyer O, Infield D, Jensen PH, et al. Wind Energy. In: Edenhofer O, Pichs-Madruga R, Sokona Y, Seyboth K, Matschoss P, Kadner S, et al., editors. IPCC special report on renewable energy sources and climate change mitigation. Cambridge, United Kingdom and New York, NY, USA: Cambridge University Press; 2011.

76. REN21. Renewables 2018 - Global Status Report. Paris: REN21 Secretariat; 2018.

77. Schively C. Understanding the NIMBY and LULU phenomena: reassessing our knowledge base and informing future research. J Plan Lit. 2007;21(3):255-66. https://doi.org/10.1177/ 0885412206295845 . 
78. Schwenkenbecher A. What is wrong with Nimbys? Renewable energy, landscape impacts and incommensurable values. Environ Values. 2017;26(6):711-32. https://doi.org/10.3197/ $096327117 X 15046905490353$.

79. Petrova MA. NIMBYism revisited: public acceptance of wind energy in the United States. Wiley Interdiscip Rev Clim Chang. 2013;4(6):575-601. https://doi.org/10.1002/wcc.250.

80. Petrova M. From NIMBY to acceptance: toward a novel framework - VESPA - for organizing and interpreting community concerns. Renew Energy. 2016;86:1280-94. https://doi.org/10.1016/ j.renene.2015.09.047.

81. Rand J, Hoen B. Thirty years of North American wind energy acceptance research: what have we learned? Energy Res Soc Sci. 2017;29:135-48. https://doi.org/10.1016/j.erss.2017.05.019.

82. Wolsink M. Wind power implementation: the nature of public attitudes: equity and fairness instead of 'backyard motives'. Renew Sust Energ Rev. 2007;11(6):1188-207. https://doi.org/10. 1016/j.rser.2005.10.005.

83. Devine-Wright P. Place attachment and public acceptance of renewable energy: a tidal energy case study. J Environ Psychol. 2011;31(4):336-43. https://doi.org/10.1016/j.jenvp.2011.07.001.

84. Burcher L. Urban character and viewscape assessment. ISoCaRP Congress. http://www.isocarp.net/Data/case_studies/643.pdf (2005). Accessed 17/7/2018.

85. Devine-Wright P, Howes Y. Disruption to place attachment and the protection of restorative environments: a wind energy case study. J Environ Psychol. 2010;30(3):271-80. https://doi.org/10. 1016/j.jenvp.2010.01.008.

86. Becker S, Bues A, Naumann M. Zur Analyse lokaler energiepolitischer Konflikte: Skizze eines Analysewerkzeugs. Raumforsch Raumordn. 2016;74(1):39-49. https://doi.org/10. 1007/s13147-016-0380-0

87. Reusswig F, Braun F, Heger I, Ludewig T, Eichenauer E, Lass W. Against the wind: local opposition to the German Energiewende. Util Policy. 2016;41:214-27. https://doi.org/10.1016/j.jup.2016. 02.006 .

88. Zografos C, Martinez-Alier J. The politics of landscape value: a case study of wind farm conflict in rural Catalonia. Environ Plan A. 2009;41(7):1726-44. https://doi.org/10.1068/a41208.

89. Hirsh RF, Sovacool BK. Wind turbines and invisible technology: unarticulated reasons for local opposition to wind energy. Technol Cult. 2013;54(4):705-34. https://doi.org/10.1353/tech.2013.0131.

90. Ellis G, Barry J, Robinson C. Many ways to say 'no', different ways to say 'yes': applying Q-methodology to understand public acceptance of wind farm proposals. J Environ Plann Manag. 2007;50(4):517-51. https://doi.org/10.1080/ 09640560701402075 . Provides interesting insights into resistance against an offshore windpark.

91. Voigt CC, Lehnert LS, Petersons G, Adorf F, Bach L. Wildlife and renewable energy: German politics cross migratory bats. Eur J Wildl Res. 2015;61(2):213-9. https://doi.org/10.1007/s10344015-0903-y.

92. Aitken M, McDonald S, Strachan P. Locating 'power' in wind power planning processes: the (not so) influential role of local objectors. J Environ Plan Manag. 2008;51(6):777-99. https:// doi.org/10.1080/09640560802423566.

93. Abbott JA. The localized and scaled discourse of conservation for wind power in Kittitas County, Washington. Soc Nat Resour.
2010;23(10):969-85. https://doi.org/10.1080/ 08941920802438634 .

94. Weber F, Jenal C, Rossmeier A, Kühne O. Conflicts around Germany's Energiewende: discourse patterns of citizens' initiatives. 2017;36(4):117-30. https://doi.org/10.1515/ quageo-2017-0040.

95. Jimenez N. Takings claims and uniform wind farm siting regulations: establishing a limited property interest to minimize conflict. Ecol Law Quart. 2011;38(2):587-94.

96. Firestone J, Kempton W. Public opinion about large offshore wind power: underlying factors. Energy Policy. 2007;35(3):1584-98. https://doi.org/10.1016/j.enpol.2006.04.010.

97. Hoen B, Brown JP, Jackson T, Thayer MA, Wiser R, Cappers P. Spatial hedonic analysis of the effects of US wind energy facilities on surrounding property values. J Real Estate Financ Econ. 2015;51(1):22-51. https://doi.org/10.1007/s11146-014-9477-9.

98. Hamilton LC, Bell E, Hartter J, Salerno JD. A change in the wind? US public views on renewable energy and climate compared. Energy Sustain Soc. 2018;8(1):11. https://doi.org/10.1186/ s13705-018-0152-5.

99. Baxter J, Morzaria R, Hirsch R. A case-control study of support/ opposition to wind turbines: perceptions of health risk, economic benefits, and community conflict. Energy Policy. 2013;61:93143. https://doi.org/10.1016/j.enpol.2013.06.050.

100. LTWP, Lake Turkana Wind Power. Lake Turkana Wind Power Ready to Produce 310MW of Energy. https://twp.co.ke/laketurkana-wind-power-ready-to-produce-310mw-of-energy/ (2017). Accessed 10/12/2017.

101.• Schilling J, Locham R, Scheffran J. A local to global perspective on oil and wind exploitation, resource governance and conflict in northern Kenya. Confl Secur Dev. 2018;18(6):571-600. https:// doi.org/10.1080/14678802.2018.1532642. The first scientific paper on the conflict implications of wind energy in northern Kenya.

102. Danwatch. A people in the way of progress. Copenhagen: Danwatch; 2016.

103. Wolsink M. Wind power and the NIMBY-myth: institutional capacity and the limited significance of public support. Renew Energy. 2000;21(1):49-64. https://doi.org/10.1016/S09601481(99)00130-5.

104. Shaw K, Hill SD, Boyd AD, Monk L, Reid J, Einsiedel EF. Conflicted or constructive? Exploring community responses to new energy developments in Canada. Energy Res Soc Sci. 2015;8:41-51. https://doi.org/10.1016/j.erss.2015.04.003.

105. Benjaminsen TA, Bryceson I. Conservation, green/blue grabbing and accumulation by dispossession in Tanzania. J Peasant Stud. 2012;39(2):335-55. https://doi.org/10.1080/03066150.2012. 667405.

106. Lund JF, Sungusia E, Mabele MB, Scheba A. Promising change, delivering continuity: REDD+ as conservation fad. World Dev. 2017;89:124-39. https://doi.org/10.1016/j.worlddev.2016.08.005.

107. International Alert. Programming framework for international alert. London: International Alert; 2010.

108. International Alert, Engineers Against Poverty. Conflict-sensitive business practice. London: International Alert; 2006.

109. Vivekananda J, Schilling J, Smith D. Climate resilience in fragile and conflict-affected societies: concepts and approaches. Dev Pract. 2014;24(4):487-501. https://doi.org/10.1080/09614524. 2014.909384. 